\title{
Pembelajaran kooperatif dalam pendekatan penemuan terbimbing ditinjau dari prestasi belajar, kemampuan berpikir kritis, dan kepercayaan diri
}

\author{
Endah Octaningrum Wahani Sejati ${ }^{{ }^{*}}$, Djamilah Bondan Widjajanti ${ }^{2}$ \\ ${ }^{1}$ Program Studi Magister Pendidikan Matematika, Universitas Negeri Yogyakarta, Indonesia \\ 2 Jurusan Pendidikan Matematika, Universitas Negeri Yogyakarta, Indonesia \\ * Corresponding Author. E-mail: endah_octa@yahoo.co.id
}

\begin{tabular}{|c|c|}
\hline ARTICLE INFO & ABSTRACT \\
\hline $\begin{array}{l}\text { Keywords: } \\
\text { Pembelajaran koeperatif, } \\
\text { STAD, TAl, } \\
\text { Penemuan terbimbing, } \\
\text { Prestasi belajar, } \\
\text { Berpikir kritis, } \\
\text { Cooperative learning, } \\
\text { Self-confidence }\end{array}$ & $\begin{array}{l}\text { Penelitian ini bertujuan untuk mendeskripsikan keefektifan model pembelajaran kooperatif } \\
\text { tipe Student Teams-Achievement Divisions (STAD) dan Team-Assisted Individualization (TAI) } \\
\text { dalam pendekatan penemuan terbimbing pada materi bangun ruang sisi datar ditinjau dari } \\
\text { prestasi belajar, kemampuan berpikir kritis, dan kepercayaan diri siswa, dan membandingkan } \\
\text { keefektifan antara kedua model pembelajaran tersebut. Penelitian ini merupakan penelitian } \\
\text { eksperimen semu. Populasi mencakup seluruh siswa kelas VIII SMP Negeri } 11 \text { Yogyakarta dan } \\
\text { sampel diambil dua kelas secara acak dari } 4 \text { kelas yang ada. Analisis univariat dengan statistik } \\
\text { uji one sample t-test dan uji paired sample } t \text { test pada taraf signifikansi } 5 \% \text { dilakukan untuk } \\
\text { menguji keefektifaan model pembelajaran. Uji Multivariat Analysis of Variance (MANOVA) } \\
\text { dilakukan untuk membandingkan keefektifaan kedua model pembelajaran. Hasil penelitian } \\
\text { menunjukkan bahwa model pembelajaran kooperatif tipe STAD dan TAl dalam pendekatan } \\
\text { penemuan terbimbing pada materi bangun ruang sisi datar masing-masing efektif ditinjau dari } \\
\text { ketiga variabel terikat. Hasil penelitian juga menunjukkan bahwa terdapat perbedaan signifikan } \\
\text { prestasi belajar dan kemampuan berpikir kritis antara kelompok model pembelajaran } \\
\text { kooperatif tipe STAD dan TAl, namun tidak terdapat perbedaan signifikan jika ditinjau dari } \\
\text { kepercayaan diri siswa. }\end{array}$ \\
\hline
\end{tabular}

This study aimed to describe the effectiveness of the cooperative learning model of Student Teams-Achievement Divisions (STAD) and Team-Assisted Individualization (TAI) types using the guided discovery approach in learning polyhedra viewed from the learning achievement, critical thinking ability, and self-confidence of the students, and compare the effectiveness of both learning models. This study was quasi-experimental. The research population comprised four classes of eighth-grade students of SMP Negeri 11 (Junior High School) in Yogyakarta, Indonesia and the sample of two classes was established randomly from the four classes. Univariate analysis with statistical one-sample t-test and paired sample t-test at a significance level of 5\% was carried out to test the effectiveness of the learning model. The Multivariate Analysis of Variance (MANOVA) test was performed to compare the effectiveness of the two learning models. The results showed that the cooperative learning model of STAD and TAI types using the guided discovery approach on the material of polyhedra respectively effective in terms of the three dependent variables. The results also showed that there were significant differences in learning achievement and critical thinking skills between the cooperative learning model of STAD and TAI types groups, but there were no significant differences in terms of students' selfconfidence.

\section{SCAN ME}

This is an open access article under the CC-BY-SA license

\section{How to Cite:}

Sejati, E. O. W., \& Widjajanti, D. B. (2019). Pembelajaran kooperatif dalam pendekatan penemuan terbimbing ditinjau dari prestasi belajar, kemampuan berpikir kritis, dan kepercayaan diri. PYTHAGORAS: Jurnal Pendidikan Matematika, 14(2), $150-162$. doi: https://doi.org/10.21831/pg.v14i2.26420

https://doi.org/10.21831/pg.v14i2.26420 


\section{PENDAHULUAN}

Pada era globalisasi semua pihak memungkinkan mendapat informasi secara cepat dan mudah dari berbagai sumber sehingga era globalisasi dirasakan merupakan ajang persaingan bebas. Setiap individu dituntut dapat memiliki kemampuan untuk menindaklanjuti informasi sehingga dapat bersaing. Untuk menghadapi kondisi tersebut, setiap individu memerlukan kemampuan dalam berpikir kritis. Kemampuan berpikir kritis menurut Arend (2009, p.2) merupakan keterampilan yang dapat mengembangkan kemampuan analisis. Sedangkan Renstein dan Lander (1990, p.80) menyebutkan bahwa berpikir kritis adalah sebuah proses memahami bagaimana berpikir dan belajar, menggunakan keterampilan yang lebih tinggi untuk memahami isu-isu, menganalisis, mensintesis, dan menilai ide-ide logis. Dengan demikian, kemampuan berpikir kritis penting dimiliki untuk menghadapi persaingan global.

Terdapat beberapa elemen-elemen penting dalam berpikir kritis yang harus dipelajari oleh siswa agar dapat memiliki kemampuan berpikir kritis sebagaimana dikemukakan oleh Orlich, Harder, Callahan, Trevisan, dan Brown (2010, p.287) yaitu "identifying issues, identifying relationships between elements, deducing implications, infering motives, combining independent elements to create new patternss of thought (creativity), and making original interpretations". Pendapat tersebut mengungkapkan enam elemen yang harus dipelajari oleh siswa dalam kemampuan berpikir kritis yaitu mengidentifikasi isu-isu, mengidentifikasi hubungan antara unsur-unsur, menyimpulkan implikasi, menyimpulkan motif, menggabungkan unsur-unsur independen untuk menciptakan pola-pola baru pemikiran (kreativitas) dan membuat interpretasi asli.

Kemampuan berpikir kritis menurut Kuebli, Harvey, dan Korn (2010, p.142) didefinisikan sebagai kemampuan dalam mengingat, menganalisis, memahami, mengaplikasi, menyimpulkan, evaluasi, dan sintesis. Sementara itu, Bassham, Irwin, Nardone, dan Wallace (2011, p.1) berpendapat bahwa berpikir kritis merujuk pada berbagai keterampilan kognitif dan disposisi intelektual yang dibutuhkan untuk secara efektif mengidentifikasi, menganalisis, dan mengevaluasi argumen dan klaim kebenaran; untuk menemukan dan mengatasi bias dan prasangka pribadi; untuk merumuskan dan menyajikan alasan yang meyakinkan untuk mendukung kesimpulan; dan membuat masuk akal, keputusan cerdas tentang apa yang dipercaya dan apa yang dilakukan. Kemampuan berpikir kritis dalam penelitian ini didefinisikan sebagai kemampuan untuk mengidentifikasi, menganalisis masalah, mengevaluasi semua aspek yang ada dalam situasi atau masalah, dan menarik kesimpulan berdasarkan bukti dan pertimbangan.

Selain melihat kemampuan berpikir kritis, dalam ranah pengetahuan terdapat prestasi belajar. Dalam matematika kemampuan yang diharapkan umumnya dari hasil proses belajar lebih banyak berkaitan dengan aspek kognitif. Pencapaian hasil belajar pada ranah ini digambarkan dengan prestasi belajar dan dikaitkan dengan pencapaian kompetensi dasar yang diberikan. Prestasi menurut Arends dan Kilcher (2010, p.59) merupakan kepuasan tersendiri bagi siswa ketika berhasil mempelajari mata pelajaran tertentu atau mendapatkan keterampilan dalam menyelesaikan suatu yang dirasa sulit dan akhirnya berhasil dalam usahanya.

Untuk mengetahui keberhasilan seseorang dalam proses pembelajaran, maka perlu dilaksanakan evaluasi untuk menentukan hasil yang diperoleh dalam pelaksanaan pembelajaran. Hasil yang diperoleh dalam pelaksanaan pembelajaran dalam dunia pendidikan biasa dikenal dengan sebagai prestasi belajar. Menurut Lawrence dan Vimala (2012, p.211) prestasi adalah ukuran pengetahuan yang didapat di pendidikan formal yang biasanya ditunjukkan dengan nilai tes, kelas, poin kelas, rata-rata dan derajat. Tingkat prestasi siswa dinilai dari skor yang diperoleh pada saat ujian. Selain itu, Linn, Bond, Carr, Darling-Hammond, Harris, Hess, dan Shulman (2009, p.9) menyatakan bahwa prestasi adalah status pencapaian pengetahuan, pemahaman, dan keterampilan terhadap materi yang telah dijalani siswa pada waktu yang ditentukan. Lebih lanjut Linn et al. (2009, p.28) menyatakan bahwa untuk mengukur prestasi yang paling umum digunakan adalah tes standar.

Berdasarkan pernyataan Lefrancois $(1985$, p.255) ada beberapa hal terkait prestasi belajar, yakni prestasi belajar diukur menggunakan tes; tes prestasi digunakan untuk mengukur pembelajaran sebelumnya dan tes prestasi belajar terbatas pada mata pelajaran atau sebagian dari mata pelajaran tertentu, sehingga untuk mengetahui prestasi belajar digunakan alat ukur yang disebut tes hasil belajar. Tes hasil belajar terdiri dari seperangkat soal atau pertanyaan yang merupakan penjabaran dari materi yang dipelajari siswa. Masing-masing soal atau pertanyaan menggambarkan materi belajar dan mencerminkan indikator dari kompetensi dasar yang diterapkan. Banyak faktor yang mempengaruhi prestasi seseorang, menurut Arthur, Grainger, \& Wray (2006, p.24) beberapa faktor yang mempengaruhi prestasi ialah motivasi, kepercayaan diri, bakat alami, kemauan untuk tekun, kepribadian bahkan keadaan kesehatan. 
Prestasi belajar dalam penelitian ini didefinisikan sebagai hasil belajar ranah kognitif dari usaha dan kemampuan yang dimiliki siswa setelah menerima pengalaman belajar untuk mencapai tujuan pembelajaran matematika pada materi bangun ruang sisi datar berupa penguasaan kompetensi dasar materi bangun ruang sisi datar yang akan diukur dengan menggunakan tes prestasi belajar. Hasil ujian nasional salah satu SMP Negeri di Yogyakarta menunjukkan bahwa persentase penguasaan pada materi bangun ruang sisi datar masih perlu ditingkatkan. Hal ini ditunjukkan dari hasil ujian nasional pada tahun 2011/2012 dan 2012/2013, yaitu disajikan pada Tabel 1.

Tabel 1. Persentase Penguasaan pada Materi Bangun Ruang Sisi Datar

\begin{tabular}{lcc}
\hline Kemampuan yang diuji & Tahun & Sekolah \\
\hline Menentukan unsur-unsur pada bangun ruang & 2012 & 74,48 \\
& 2013 & 90,91 \\
\hline Menyelesaikan masalah yang berkaitan dengan kerangka atau jaring-jaring & 2012 & 96,50 \\
bangun ruang & 2013 & 61,16 \\
\hline Menyelesaikan masalah yang berkaitan dengan luas permukaan bangun ruang & 2012 & 38,12 \\
& 2013 & 45,73 \\
\hline Menyelesaikan masalah yang berkaitan dengan volume bangun ruang & 2012 & 59,09 \\
& 2013 & 51,24 \\
\hline Rata-rata & 2012 & 67,05 \\
& 2013 & 62,26 \\
\hline
\end{tabular}

(Sumber: BSNP, 2012; 2013)

Tabel 1 menunjukkan bahwa penguasaan pada materi bangun ruang sisi datar siswa di salah satu SMP Negeri di Yogyakarta masih perlu ditingkatkan. Hal ini dikarenakan rata-rata persentase penguasaan belum mencapai $70 \%$.

Dalam implementasi kurikulum, belajar matematika tidak hanya mengembangkan ranah pengetahuan dan keterampilan, namun ranah sikap tidak kalah pentingnya. Ketika siswa berusaha menyelesaikan masalah matematis, antara lain diperlukan rasa ingin tahu, ulet, percaya diri, melakukan refleksi atas cara berpikir. Sikap positif siswa dalam menghadapi matematika dan keyakinannya dapat mempengaruhi prestasi mereka dalam matematika. Hasil penelitian Hannula, Maijala, dan Pehkonen (2004, p.23) menyatakan bahwa kepercayaan diri merupakan variabel lain yang memprediksi pengembangan diri di masa depan. Kepercayaan diri siswa sebagian besar memprediksi pengembangan diri di masa depan, serta perkembangan orientasi keberhasilan dan prestasi. Sejalan juga dengan hasil penelitian Susanti, Budiyono, dan Sujadi $(2013$, p.303) menyatakan bahwa siswa yang percaya dirinya tinggi maka prestasi belajarnya juga tinggi.

Kepercayaan diri menurut Lauster (Ghufron \& Risnawita, 2010, p.34) diperoleh dari pengalaman hidup. Kepercayaan diri merupakan salah satu aspek kepribadian yang berupa keyakinan akan kemampuan diri seseorang sehingga tidak terpengaruh oleh orang lain dan dapat bertindak sesuai kehendak, gembira, optimis, cukup toleran, dan bertanggung jawab. Seseorang yang percaya pada kemampuan diri sendiri akan dapat menyelesaikan masalah-masalah yang dihadapi dan diperoleh dari pengalaman hidup sehari-hari. Hal tersebut sejalan dengan pendapat Manning dan Curtis (2003, p.27) bahwa kepercayaan pada satu kemampuan memberikan kekuatan diri dalam untuk menyelesaikan tugas sulit yang akan datang. Selain itu Hannula et al. (2004, p.17) menyatakan bahwa pembelajaran matematika dipengaruhi oleh siswa yang mempunyai keyakinan kemampuan diri terutama rasa percaya diri.

Orang yang memiliki kepercayaan diri akan memiliki ciri-ciri seperti yang diungkapkan oleh JIST Life (2006, pp.238-243) yaitu dapat menyelesaikan hampir semua pekerjaan yang diambil, terus mencoba (tidak ragu untuk mencoba) meskipun gagal. Sedangkan Srivastava (2013, p.42) mengungkapkan bahwa orang yang percaya diri akan memiliki pandangan positif terhadap dirinya dan situasi yang sedang mereka alami. Mereka pun percaya pada kemampuan mereka sendiri dengan alasan yang realistis, serta mereka akan mampu untuk melakukan apa yang mereka inginkan, rencanakan dan harapkan. Apabila harapan mereka tidak terwujud maka mereka terus berpikir positif dan menerima semua yang terjadi. Kepercayaan diri dalam penelitian ini didefinisikan sebagai sikap seseorang yang percaya pada kemampuan yang dimiliki, optimis, berani, tidak terpengaruh oleh orang lain, dan mampu menyelesaikan masalah. 
Fakta terkait kepercayaan diri siswa diungkap peneliti melalui pra penelitian yang dilakukan di salah satu SMP Negeri di Yogyakarta dengan membagikan angket kepercayaan diri kepada siswa kelas IX. Angket kepercayaan diri ini peneliti ambil dari instrumen tesis Wartiningsih (2011, pp.341-342) dan berpedoman pada kriteria yang ditulis Widoyoko (2009, p.238). Hasil angket kepercayaan diri siswa pada pra penelitian disajikan pada Tabel 2.

Tabel 2. Hasil Angket Kepercayaan Diri Siswa (Pra Penelitian)

\begin{tabular}{lcc}
\hline Kriteria & Banyak Siswa & Persentase \\
\hline Sangat Baik & 0 & $0 \%$ \\
Baik & 14 & $45 \%$ \\
Cukup & 14 & $45 \%$ \\
Kurang & 3 & $10 \%$ \\
Sangat Kurang & 0 & $0 \%$ \\
\hline
\end{tabular}

Tabel 2 menunjukkan bahwa ketercapaian sikap yaitu kepercayaan diri belumlah optimal karena persentase kepercayaan diri belum mencapai pada kategori sangat baik, dan masih ada persentase $10 \%$ pada kategori kurang, sehingga perlu adanya upaya untuk meningkatkan kepercayaan diri siswa.

Menyikapi permasalahan-permasalahan yang muncul, terutama berkaitan dengan praktik pembelajaran matematika di kelas maka perlu diterapkannya pembelajaran yang efektif. Pembelajaran efektif menurut Miarso (Warsita, 2008, p.201) adalah yang menghasilkan belajar bermanfaat dan bertujuan bagi peserta didik, melalui pemakaian prosedur yang tepat. Sedangkan karakteristik pembelajaran matematika yang efektif menurut Lim (Cai, Kaiser, Perry, \& Wong, 2009, p.127) meliputi aktivitas berpusat pada siswa yang mendorong pada pemahaman konseptual, berhubungan dengan pengalaman siswa sehari-hari, siswa memahami apa yang diajarkan dan dapat menggunakan apa yang mereka pelajari untuk memecahkan masalah, perencanaan yang baik untuk aktivitas belajar siswa, siswa aktif berpartisipasi pada aktivitas yang menyenangkan dan bermakna, dan menggunakan bantuan dalam pembelajaran yang dapat meningkatkan pemahaman siswa.

Keefektifan pembelajaran matematika SMP dalam penelitian ini didefinisikan dengan pencapaian tujuan pembelajaran secara tepat berdasarkan kriteria ketuntasan minimal dan indikator yang ditetapkan untuk setiap unit bahan pelajaran matematika SMP melalui proses kegiatan belajar matematika (Kyriacou, 2009, p.7; Dean, 2000, p.51; Kemp, Morrison, \& Ross, 1994, p.289). Mengingat pentingnya meningkatkan prestasi belajar, kemampuan berpikir kritis, dan kepercayaan diri siswa terhadap matematika, maka upaya untuk menanggulanginya harus segera dilakukan. Salah satu solusinya dengan diterapkan model pembelajaran yang sesuai dengan standar proses dalam kurikulum pendidikan, dan secara teoritis diduga dapat mengatasi masalah dari prestasi belajar, kemampuan berpikir kritis dan kepercayaan diri siswa terhadap matematika.

Salah satu model pembelajaran yang dapat diterapkan guru untuk meningkatkan pemahaman konsep matematika adalah discovery learning. Hal ini sejalan dengan pendapat Bergstrom dan O'Brien (Slavin, 2006, p.245) yaitu pada pembelajaran discovery siswa didorong untuk belajar secara aktif dengan konsep-konsep dan prinsipprinsip, dan guru mendorong siswa memperoleh pengalaman dan melakukan percobaan yang memungkinkan mereka menemukan sendiri prinsip-prinsip. Model pembelajaran discovery learning ada 2 macam yaitu penemuan murni (pure discovery) dan penemuan terbimbing (guided discovery). Namun untuk siswa SMP lebih tepat dilakukan pembelajaran guided discovery, karena siswa SMP masih membutuhkan peran guru dalam membimbing untuk menemukan pemahaman konsep matematika. Hal ini sejalan dengan pendapat Shulman dan Keisler (Mayer, 2004, p.15) yang mengungkapkan bahwa "guided discovery is generally more effective than pure discovery in promoting learning and transfer to new problem". Selain itu, guided discovery lebih efektif karena membantu siswa menemukan dua kriteria penting dalam pembelajaran aktif (Apino, 2016), yaitu keaktifan atau ketepatan dalam menghubungkan pengetahuan yang akan digunakan untuk membuat pengertian terhadap informasi baru yang datang, dan menggabungkan informasi baru yang datang dengan pengetahuan dasar yang tepat.

Tiga ciri utama belajar menemukan menurut Biknell-Holmes dan Hoffman (Castronova, 2002, p.2) yaitu mengeksplorasi dan memecahkan masalah untuk menciptakan, menggabungkan dan menggeneralisasi pengetahuan; berpusat pada siswa/mahasiswa; dan kegiatannya untuk menggabungkan pengetahuan baru dan pengetahuan yang sudah ada. Sedangkan Orlich et al. (2010, p.306) menyatakan bahwa pembelajaran dengan penemuan merupakan proses penyelidikan dimana siswa mengajukan pertanyaan dan mencari jawaban mungkin atas masalah tersebut. 
Langkah-langkah yang harus ditempuh dalam pembelajaran dengan pendekatan penemuan terbimbing menurut Westwood (2008, p.29) terdiri dari: (a) mengidentifikasi topik atau masalah yang akan diajukan; (b) guru dan siswa bekerja sama untuk menghubungkan ide-ide dalam menyelidiki topik; (c) siswa bekerja secara individu atau dalam kelompok kecil untuk mengumpulkan dan menginterpretasikan data; (d) menarik kesimpulan dan kesimpulan sementara bersama seluruh kelompok dan dimodifikasi jika perlu; (e) guru meluruskan kesalahpahaman, meringkas temuan-temuan dan membantu untuk menarik kesimpulan. Sedangkan menurut Eggen dan Kauchank (2012, p.182) bahwa dalam merencanakan pelajaran dengan pembelajaran penemuan terbimbing melibatkan tiga langkah penting yaitu: (1) mengidentifikasi topik, (2) menentukan tujuan belajar, (3) menyiapkan contoh dan non contoh.

Proses pembelajaran di kelas agar memotivasi peserta didik untuk berpartisipasi aktif, interaktif, dan menyenangkan yaitu dengan mengimplementasikan model pembelajaran kooperatif. Model pembelajaran kooperatif merupakan model yang baik untuk diterapkan pada pembelajaran di kelas, hal ini didukung dengan penelitian yang dilaksanakan oleh beberapa peneliti (misalnya: Adesoji \& Ibraheem, 2009; Herrmann, 2013; Molla \& Muche, 2018; Nneji, 2011; Shininger, 2006; Yasna, 2016; Zakaria, Chin, \& Daud, 2010). Hasil-hasil penelitian tersebut menunjukkan bahwa pembelajaran kooperatif dapat memiliki dampak positif pada pembentukan sikap yang lebih positif terhadap matematika di kalangan siswa dan meningkatkan prestasi akademik siswa. Dua diantara model pembelajaran kooperatif yaitu tipe Student Teams-Achievement Divisions (STAD) dan Team-Assisted Individualization (TAI).

Alasan memilih model kooperatif tipe STAD menurut Slavin (2006, p.257) bahwa salah satu pembelajaran kooperatif yang efektif adalah STAD. STAD terdiri atas tahapan pengajaran yang teratur, belajar dalam kelompok dengan kemampuan yang heterogen, pemberian kuis dan penghargaan kepada tim yang anggotanya unggul. Belajar dalam kelompok yang heterogen memungkinkan terjadinya proses berbagi pengetahuan antara anggota kelompok. Dalam tipe STAD menekankan penggunaan tujuan kelompok dan keberhasilan kelompok yang akan tercapai bila semua anggota kelompok mempelajari materi yang sedang diajarkan. Tugas peserta didik bukanlah melakukan sesuatu tetapi mempelajari sesuatu sebagai sebuah kelompok, dimana kerja kelompok dilakukan sampai semua anggota kelompok menguasai materi yang sedang dipelajari. Adanya kuis dan penghargaan bagi kelompok yang mampu mencapai nilai yang baik dapat meningkatkan sikap positif siswa untuk lebih giat belajar yang pada akhirnya dapat meningkatkan prestasi belajar.

Berbeda dengan tipe STAD, ciri khas tipe TAI adalah peserta didik secara individual belajar materi yang telah diberikan oleh guru. Hasil dari belajar individual dibawa ke dalam kelompok untuk didiskusikan dengan anggota yang lain. Semua anggota kelompok saling membantu satu sama lain dalam menghadapi masalah dan bertanggung jawab atas jawaban sebagai tanggung jawab bersama. Sejalan dengan pernyataan ini, Slavin (1995, p.98) menyatakan bahwa TAl juga melatih siswa untuk bersosialisasi dengan baik, ditemukan adanya pengaruh positif pada hubungan dan sikap terhadap siswa yang terlambat secara belajar.

Peneliti tertarik untuk membandingkan model kooperatif tipe STAD dan TAI dalam pendekatan penemuan terbimbing karena pembelajaran penemuan terbimbing dapat mengeksplorasi dan memecahkan masalah serta membuat dan menggeneralisasikan pengetahuan siswa melalui bimbingan guru di kelas. Siswa dibimbing untuk melakukan aktivitas penemuan terhadap konsep matematika yang baru dan siswa akan belajar mendefinisikan konsep, dan menerapkan topik pada situasi yang baru. Selain itu, dengan pembelajaran penemuan terbimbing akan membuat pengetahuan yang diperoleh bertahan lebih lama atau lama diingat karena konsep dan informasi itu siswa temukan sendiri, hal ini sesuai dengan pernyataan Dahar (2011, p.80). Dari dua tipe model kooperatif tersebut memiliki kesamaan dan perbedaan. Persamaannya terletak pada pengelompokan peserta didik secara heterogen dan memberikan penghargaan kepada kelompok yang memiliki skor tinggi. Sedangkan perbedaannya adalah model STAD hanya menggunakan pola pengajaran tunggal dan TAI menggabungkan pembelajaran kooperatif dengan pengajaran individual.

Berdasarkan uraian yang telah dikemukakan menunjukkan bahwa prestasi belajar, kemampuan berpikir kritis, dan kepercayaan diri siswa dalam pembelajaran matematika masih perlu ditingkatkan. Di samping itu, dalam proses pembelajaran matematika diperlukannya inovasi dalam pelaksanaan dan penerapan model pembelajaran yang sesuai dengan kebutuhan peserta didik. Dengan demikian, tujuan penelitian ini adalah untuk mendeskripsikan keefektifan model pembelajaran kooperatif tipe STAD dan TAI dalam pendekatan penemuan terbimbing pada materi bangun ruang sisi datar ditinjau dari prestasi belajar, kemampuan berpikir kritis, dan kepercayaan diri siswa 
SMP, serta membandingkan keefektifaan kedua model pembelajaran tersebut ditinjau dari prestasi belajar, kemampuan berpikir kritis, dan kepercayaan diri siswa SMP.

\section{METODE}

Penelitian ini merupakan penelitian eksperimen semu dengan desain pretest-posttest nonequivalent group design. Populasi mencakup seluruh siswa kelas VIII SMP Negeri 11 Yogyakarta, sedangkan sampel penelitian terdiri dari dua kelas eksperimen yang diambil secara acak dari empat kelas VIII yang ada, sehingga diperoleh kelas VIII-A sebagai kelompok pembelajaran kooperatif tipe STAD dalam pendekatan penemuan terbimbing dan kelas VIII-B sebagai kelompok yang menerapkan pembelajaran pembelajaran kooperatif tipe TAl dalam pendekatan penemuan terbimbing.

\section{Prosedur Penelitian}

Pada masing-masing kelas eksperimen, diberikan pretest prestasi belajar, kemampuan berpikir kritis (KBK) serta angket kepercayaan diri (KD) sebelum diberikan perlakuan. Hal tersebut bertujuan untuk mengetahui kemampuan awal siswa. Selanjutnya, setelah diberikan perlakuan, kedua kelas diberikan posttest prestasi belajar, kemampuan berpikir kritis, serta angket kepercayaan diri untuk mengetahui kemampuan siswa pada variabel tersebut setelah diberikan perlakuan.

\section{Data, Instrumen, dan Teknik Pengumpulan Data}

Instrumen yang digunakan yaitu soal tes prestasi belajar berbentuk pilihan ganda terdiri dari 20 butir soal dan soal tes kemampuan berpikir kritis berbentuk uraian terdiri dari 3 butir soal. Baik tes prestasi dan kemampuan berpikir kritis masing-masing mengukur indikator pada materi bangun ruang sisi datar. Instrumen untuk mengukur kepercayaan diri yaitu berupa angket yang terdiri dari 25 butir pernyataan dengan skala likert.

\section{Teknik Analisis Data}

Analisis inferensial dilakukan untuk mengambil kesimpulan berdasarkan data yang telah diperoleh selama proses penelitian berlangsung. Analisis inferensial ini terdiri dari uji keefektifan untuk masing-masing variabel dan uji perbandingan keefektifan kedua model pembelajaran secara simultan (melibatkan semua variabel terikat secara bersamaan). Adapun kriteria pembelajaran dikatakan efektif yaitu: (a) rata-rata skor prestasi belajar dan kemampuan berpikir kritis minimal 70; dan (b) rata-rata skor angket kepercayaan diri siswa dalam pembelajaran matematika pada skor akhir lebih baik dari skor awal dan berada pada kategori minimal "tinggi" yaitu skor yang diperoleh minimal 86.

Data-data yang diperoleh selama penelitian berlangsung harus memenuhi uji asumsi terlebih dahulu sebelum dilakukan uji hipotesis. Jika semua asumsi telah terpenuhi maka dapat dilanjutkan dengan menganalisis keefektifan kedua model pembelajaran ditinjau dari masing-masing variabel dengan menggunakan one sample t-test dan paired sample t-test dengan kriteria hipotesis nol ditolak apabila nilai signifikansi kurang dari 0,05.

Adapun untuk analisis perbedaan keefektifan secara simultan digunakan uji Multivariate Analysis of Variance (MANOVA) $T^{2}$ Hotelling (Stevens, 2009, p.148). Taraf signifikansi yang digunakan pada uji keefektifan adalah 0,05. Sebelum dianalisis data terlebih diuji asumsi normalitas secara multivariat dan homogenitas data. Pengecekan asumsi normalitas multivariat dilakukan menggunakan jarak Mahalanobis dengan menggunakan kriteria Chi square $\chi^{2}$ yaitu persentase nilai $d_{i}{ }^{2}<\chi_{p}{ }_{p}(0,5)$ mendekati $50 \%$ maka dapat dikatakan bahwa populasi tersebut berdistribusi normal multivariat (Johnson \& Wichern, 2007, p.182). Adapun asumsi homogenitas matriks kovarian menggunakan uji Box-M dengan kriteria penolakan hipotesis nol apabila nilai signifikansi kurang dari 0,05. Kemudian analisis dilanjutkan dengan uji independent sample $t$-test untuk mengetahui perbedaan keefektifaan ditinjau dari masing-masing variabel terikat (Stevens, 2009, p.147).

\section{HASIL DAN PEMBAHASAN}

\section{Hasil Penelitian}

Hasil penelitian ini terdiri dari hasil uji keefektifan kedua model pembelajaran dengan menggunakan one sample t-test seperti disajikan pada Tabel 3. 
Tabel 3. Hasil Uji Keefektifan Pembelajaran

\begin{tabular}{lll}
\hline Model & Variabel & Sig. $t$ \\
\hline \multirow{3}{*}{ STAD dalam Penemuan Terbimbing } & Prestasi & 0,028 \\
& KBK & 0,043 \\
& KD & 0,001 \\
TAl dalam Penemuan Terbimbing & Prestasi & 0,000 \\
& KBK & 0,000 \\
& KD & 0,000 \\
\hline
\end{tabular}

Keterangan: KBK = Kemampuan Berpikir Kritis; KD = Kepercayaan Diri

Hasil uji keefektifan kedua model pembelajaran dengan menggunakan paired sample t-test disajikan pada Tabel 4.

Tabel 4. Hasil Uji Keefektifan Pembelajaran

\begin{tabular}{lll}
\hline Model & Variabel & Sig. $t$ \\
\hline STAD dalam Penemuan Terbimbing & KD & 0,000 \\
TAl dalam Penemuan Terbimbing & KD & 0,000 \\
\hline
\end{tabular}

Berdasarkan Tabel 3 dan Tabel 4 terlihat bahwa pada kelompok siswa dengan pembelajaran STAD dalam penemuan terbimbing diperoleh nilai signifikansi untuk semua variabel kurang dari 0,05 . Hal ini berarti hipotesis nol ditolak. Dengan kata lain model pembelajaran STAD dalam penemuan terbimbing pada materi bangun ruang sisi datar efektif ditinjau dari prestasi belajar, kemampuan berpikir kritis, dan kepercayaan diri siswa. Selain itu jika melihat kelompok siswa dengan pembelajaran TAI dalam penemuan terbimbing diperoleh nilai signifikansi untuk semua variabel kurang dari 0,05, itu artinya hipotesis nol ditolak. Dengan demikian pembelajaran TAl dalam penemuan terbimbing pada materi bangun ruang sisi datar efektif ditinjau dari prestasi belajar, kemampuan berpikir kritis, dan kepercayaan diri siswa.

Sebelum melakukan uji perbandingan keefektifan kedua model pembelajaran maka terlebih dahulu dilakukan uji asumsi. Adapun hasil uji asumsi normalitas multivariat dapat dilihat pada Tabel 5.

Tabel 5. Hasil Uji Normalitas Multivariat

\begin{tabular}{lcc}
\hline Kelompok & $d_{i}^{2}$ Sebelum Perlakuan & $d_{i}^{2}$ Setelah Perlakuan \\
\hline STAD dalam Penemuan Terbimbing & $47 \%$ & $50 \%$ \\
TAI dalam Penemuan Terbimbing & $53 \%$ & $56 \%$ \\
\hline
\end{tabular}

Berdasarkan Tabel 5, diperoleh informasi bahwa persentase nilai $d_{i}^{2}<\chi^{2}{ }_{3}(0,5)$ untuk kelompok STAD dan TAI dalam penemuan terbimbing sebelum dan sesudah perlakuan berdistribusi normal. Adapun untuk hasil uji asumsi homogenitas matriks kovarians dapat dilihat pada Tabel 6 .

Tabel 6. Hasil Uji Homogenitas Matriks Kovarians

\begin{tabular}{lcc}
\hline & Sebelum Perlakuan & Setelah Perlakuan \\
\hline Box's $M$ & 10,863 & 9,618 \\
$F$ & 1,721 & 1,524 \\
Sig. & 0,112 & 0,166 \\
\hline
\end{tabular}

Berdasarkan Tabel 6, diperoleh informasi bahwa nilai signifikansi uji Box's $M$ sebelum dan setelah perlakuan adalah 0,112 dan 0,166 lebih dari 0,05 maka matriks kovarians kedua kelompok sama (asumsi homogenitas matriks kovarians terpenuhi).

Hal selanjutnya yang dilakukan adalah menguji perbedaan keefektifan antara model pembelajaran kooperatif tipe STAD dan TAI dalam pendekatan penemuan terbimbing ditinjau dari ketiga variabel terikat. Multivariate Analysis of Variance (MANOVA) $T^{2}$ Hotelling pada taraf signifikan 5\% digunakan untuk menguji hipotesis penelitian. Hasil analisis data menunjukkan bahwa nilai signifikansi untuk data sebelum perlakuan adalah sebesar 0,397 lebih besar dari taraf signifikansi 0,05. Artinya Hipotesis nol diterima. Dengan kata lain kondisi awal kedua kelompok sama. Untuk data setelah perlakuan, hasil analisis menunjukkan bahwa nilai signifikansi yang diperoleh sebesar 0,008 kurang dari taraf signifikansi 0,05 . Artinya terdapat perbedaan keefektifan antara kedua pembelajaran. 
Karena terdapat perbedaan keefektifan pembelajaran kedua kelas ditinjau dari ketiga aspek tersebut maka dilakukan uji lanjut univariat.

Uji lanjut univariat dilakukan menggunakan independent sample $t$-test, dimana hasil pengujiannya disajikan pada Tabel 7.

Tabel 7. Hasil Uji Independent Sample t-test Setelah Perlakuan

\begin{tabular}{lrr}
\hline Aspek Tinjauan & $t$ & Sig. \\
\hline Prestasi & 3,616 & 0,001 \\
KBK & 2,774 & 0,007 \\
KD & $-3,025$ & 0,998 \\
\hline
\end{tabular}

Berdasarkan Tabel 7 dapat dilihat bahwa prestasi dan kemampuan berpikir kritis siswa antara kelas yang belajar dengan model pembelajaran kooperatif tipe STAD dalam pendekatan penemuan terbimbing dan kelas yang belajar dengan model kooperatif tipe TAI dalam pendekatan penemuan terbimbing berbeda signifikan. Namun ditinjau dari kepercayaan diri siswa, kedua model pembelajaran tidak berbeda secara signifikan.

\section{Pembahasan}

Hasil penelitian menunjukkan bahwa model pembelajaran kooperatif tipe STAD dan TAI dalam pendekatan penemuan terbimbing pada materi bangun ruang sisi datar efektif ditinjau dari prestasi belajar. Hal ini terjadi karena pada pembelajaran STAD dalam penemuan terbimbing menggunakan tahapan berkelompok untuk bekerja sama di kelas dan mengerjakan kuis secara individu yang membuat siswa harus memahami konsep materi setelah melaksanakan pembelajaran. Hal ini sesuai dengan pendapat Slavin (1995, p.5) bahwa kesuksesan kelompok dapat tercapai jika setiap peserta didik melaksanakan tanggung jawab individu. Tanggung jawab difokuskan pada kegiatan anggota kelompok dalam membantu satu sama lain untuk belajar dan memastikan tiap orang dalam kelompok menguasai materi dan siap mengerjakan kuis secara individu. Hal ini sesuai dengan kerangka pikir peneliti, yakni ketujuh langkah model pembelajaran kooperatif tipe STAD dalam penemuan terbimbing mampu meningkatkan prestasi belajar. Hal ini juga sesuai dengan hasil penelitian yang dilakukan oleh Shininger (2006, p.37). Hasil penelitian tersebut menunjukkan bahwa STAD dapat meningkatkan prestasi akademik siswa dan memberi kemajuan pada aspek penghargaan diri (self-esteem) siswa sebagai pelajar serta interaksi sosial dengan siswa lain.

Pada pembelajaran TAI dalam penemuan terbimbing memberikan kesempatan kepada siswa untuk mengembangkan pengetahuan individunya. Dalam pembelajaran kooperatif tipe TAl juga memberikan kesempatan kepada siswa untuk bertukar pendapat tentang materi yang sedang dibahas. Hal ini sependapat dengan Trianto (2010, p.59) bahwa pembelajaran kooperatif unggul dalam membantu siswa dalam memahami konsep-konsep yang sulit. Selain itu, pembelajaran menggunakan pendekatan penemuan akan membuat pengetahuan yang diperoleh bertahan lebih lama atau lama diingat (Dahar, 2011, p. 80). Hal ini sesuai dengan kerangka pikir peneliti, yakni kedelapan langkah model pembelajaran kooperatif tipe TAI dalam penemuan terbimbing mampu meningkatkan prestasi belajar. Ditambahkan dengan hasil penelitian Amiluddin dan Sugiman (2016, p.107) bahwa pendekatan problem posing dan PBL berpengaruh positif terhadap prestasi belajar. Pendekatan problem posing dan PBL memiliki karakteristik yang hampir sama dengan penemuan terbimbing yaitu untuk pemahaman konsep dan membuat siswa menjadi aktif. Hal ini juga diperkuat dengan dengan hasil penelitian relevan yang dilakukan oleh Munawaroh (2006) yang menunjukkan bahwa model pembelajaran kooperatif tipe TAl efektif ditinjau dari prestasi belajar peserta didik.

Hasil penelitian juga menunjukkan bahwa model pembelajaran kooperatif tipe STAD dan TAI dalam pendekatan penemuan terbimbing pada materi bangun ruang sisi datar efektif ditinjau dari kemampuan berpikir kritis. Hal ini dapat terjadi karena dalam pembelajaran STAD dalam penemuan terbimbing peserta didik saling berdiskusi antar anggota kelompok untuk membahas LKS dengan langkah pendekatan penemuan terbimbing yaitu mengidentifikasi masalah, mengumpulkan data, menganalisis data, dan menarik kesimpulan. Dalam tahapan ini menurut Slavin $(1995$, p.2) setiap peserta didik dalam pembelajaran kooperatif untuk saling membantu mempelajari materi pelajaran, dalam kelompok siswa diharapkan untuk saling membantu, berdiskusi, berdebat, saling menilai pengetahuan terbaru dan saling mengisi kelemahan dalam pemahaman masing-masing. Sejalan juga dengan pendapat Borich (2007, p.373), pembelajaran kooperatif dapat meningkatkan berpikir kritis, penalaran, 
dan sikap pemecahan masalah. Tahapan selanjutnya yaitu mengerjakan kuis secara individu. Kuis dilakukan secara individu untuk membentuk tanggung jawab peserta didik.

Diperkuat dengan pendapat Roger dan David Johnson (Lie, 2004, p.31) bahwa pola penilaian yang dilakukan secara individu menyebabkan peserta didik akan merasa mempunyai tanggung jawab untuk memberikan yang terbaik untuk kelompoknya. Sejalan dengan pendapat Slavin $(1995$, p.5) bahwa kesuksesan kelompok dapat tercapai jika setiap peserta didik melaksanakan tanggung jawab individu. Diduga setiap anggota dalam kelompok harus menguasai materi dan rasa tanggung jawab dalam mengerjakan kuis, hal ini menjadi penyebab pembelajaran STAD dalam penemuan terbimbing efektif dari aspek kemampuan berpikir kritis. Hal ini diperkuat oleh hasil penelitian Sari, Nurochmah, Haryadi, dan Syaiturjim (2016, p.21) bahwa menggunakan pendekatan pembelajaran STAD secara signifikan dapat meningkatkan kemampuan pemahaman matematis siswa. Dan sesuai dengan kerangka pikir peneliti, yakni keempat langkah model pembelajaran kooperatif tipeSTAD dalam penemuan terbimbing mampu meningkatkan kemampuan berpikir kritis.

Pada kelas pembelajaran TAI dalam penemuan terbimbing terdapat tiga tahapan yang diduga dapat meningkatkan pemahaman konsep sehingga memiliki kemampuan berpikir kritis peserta didik. Yang pertama adalah peserta didik belajar secara individu dalam mengerjakan LKS dengan langkah pendekatan penemuan terbimbing. Oleh karena dilakukan secara individu maka setiap peserta didik mempunyai tingkat pemahaman yang berbeda saat mengerjakan LKS. Melalui tahapan ini, peserta didik berusaha memahami materi yang sedang dipelajari, mencoba mengerjakan sendiri permasalahan dalam LKS sesuai dengan kemampuannya sendiri. Hal ini sejalan dengan pendapat Slavin (1995, p.7), saat peserta didik memasuki bagian individual, mereka akan belajar pada tingkat kemampuan mereka sendiri. Saat itu peserta didik dapat dengan bebas mengerjakan LKS tanpa berdebat dengan teman mengenai cara mengerjakan dan tidak perlu menunggu peserta didik lain dalam mengerjakan. Setelah mengerjakan LKS secara individu, peserta didik belajar dalam kelompok. Peserta didik melakukan pengecekan terhadap hasil individualnya dan mendiskusikannya bersama anggota kelompok. Tahapan terakhir adalah dengan mengerjakan kuis secara individu.

Hasil di atas juga diperkuat dengan pendapat Trianto $(2009$, p.59) yang menyatakan bahwa pembelajaran kooperatif dapat meningkatkan kinerja siswa dalam tugas-tugas akademik, unggul dalam membantu siswa dalam memahami konsep-konsep yang sulit, dan membantu siswa menumbuhkan kemampuan berpikir kritis. Sejalan dengan itu menurut Suherman (2003, p.259) bahwa pembelajaran kooperatif dapat meningkatkan berpikir kritis serta meningkatkan kemampuan siswa dalam pemecahan masalah. Hal ini sesuai dengan kerangka pikir peneliti, yakni kelima langkah model pembelajaran kooperatif tipe TAI dalam penemuan terbimbing mampu meningkatkan kemampuan berpikir kritis.

Selain efektif terhadap prestasi dan kemampuan berpikir kritis. Hasil penelitian juga menunjukkan bahwa model pembelajaran kooperatif tipe STAD dan TAI dalam pendekatan penemuan terbimbing pada materi bangun ruang sisi datar efektif ditinjau dari kepercayaan diri siswa SMP. Pendapat Lauster (Ghufron \& Risnawita, 2010, p.34) mengungkapkan bahwa kepercayaan diri merupakan salah satu aspek kepribadian yang berupa keyakinan akan kemampuan diri seseorang sehingga tidak terpengaruh oleh orang lain dan dapat bertindak sesuai kehendak, gembira, optimis, cukup toleran, dan bertanggung jawab. Hal ini terjadi karena pada pembelajaran STAD dalam penemuan terbimbing, siswa di dalam kelompoknya melakukan diskusi dan mempresentasikan hasil diskusinya di depan kelas. Proses diskusi dan presentasi di kelas diharapkan siswa berani mengungkapkan pendapat dan memiliki sikap toleran apabila berbeda pendapat dalam setiap kelompok. Setelah pembelajaran kelompok berakhir, siswa mengerjakan kuis secara individual untuk mengetahui apakah siswa tersebut telah memahami konsep yang dibahas. Selain itu kuis juga bertujuan untuk menentukan keberhasilan kelompok, sehingga siswa mempunyai rasa tanggung jawab yang sama dalam melaksanakan tugas mereka.

Selain itu, berdasarkan pendapat Jurdak $(2009$, p.111) bahwa salah satu upaya meningkatkan kepercayaan diri siswa dalam pembelajaran matematika yaitu dengan interaksi siswa dengan guru matematika dan dengan rekan-rekan kelas selama pembelajaran matematika. Kepercayaan diri akan kemampuan yang dia miliki akan memotivasinya untuk membuat dirinya eksis di tiap kesempatan baik saat bersaing dengan teman-temannya ataupun saat dibandingkan dengan teman-temannya. Diperkuat dengan hasil penelitian Martyanti (2016, p.13) bahwa pendekatan problem solving dengan setting pembelajaran kooperatif tipe STAD dan tipe TAl efektif ditinjau dari prestasi dan self-confidence. Hal ini sesuai dengan kerangka pikir peneliti, yakni ketujuh langkah model pembelajaran kooperatif tipe STAD dalam penemuan terbimbing mampu meningkatkan kepercayaan diri yaitu salah satunya dengan diskusi dan presentasi di kelas. 
Pada pembelajaran TAI dalam penemuan terbimbing juga terdapat tahapan yaitu mempresentasikan hasil dari diskusi kelompok dan mengerjakan kuis secara individu. Pada tahapan ini dibutuhkan sikap berani menyampaikan pendapat saat terjadinya diskusi di kelas dan berjalannya proses presentasi. Selain itu sikap bertanggung jawab secara individu untuk tahapan pengerjaan kuis. Hal ini sesuai dengan pendapat Ghufron dan Risnawita (2010, p.35) bahwa individu yang mempunyai kepercayaan diri yang tinggi akan terlihat lebih tenang, tidak memiliki rasa takut (berani), dan mampu memperlihatkan kepercayaan dirinya setiap saat. Diperkuat dengan pernyataan Lauster (Ghufron \& Risnawita, 2010, p.34) bahwa kepercayaan diri merupakan salah satu aspek kepribadian yang berupa keyakinan akan kemampuan diri seseorang sehingga tidak terpengaruh oleh orang lain dan dapat bertindak sesuai kehendak, gembira, optimis, cukup toleran, dan bertanggung jawab.

Sejalan dengan pendapat Jurdak (2009, p.111) bahwa salah satu upaya meningkatkan kepercayaan diri siswa dalam pembelajaran matematika yaitu dengan interaksi siswa dengan guru matematika dan dengan rekan-rekan kelas selama pembelajaran matematika. Kepercayaan diri akan kemampuan yang dia miliki akan memotivasinya untuk membuat dirinya eksis di tiap kesempatan baik saat bersaing dengan teman-temannya ataupun saat dibandingkan dengan teman-temannya. Hal ini juga diperkuat dengan pendapat Suherman (2003, p. 259) bahwa pembelajaran kooperatif dalam matematika akan dapat membantu para siswa meningkatkan sikap positif siswa dalam matematika. Para siswa secara individu dapat membangun kepercayaan diri terhadap kemampuannya untuk menyelesaikan masalah-masalah matematika. Ditambahkan dengan hasil penelitian Martyanti $(2016$, p.13) bahwa pendekatan problem solving dengan setting pembelajaran kooperatif tipe STAD dan tipe TAl efektif ditinjau dari prestasi dan self-confidence. Hal ini sesuai dengan kerangka pikir peneliti, yakni keempat langkah model pembelajaran kooperatif tipe TAI dalam penemuan terbimbing mampu meningkatkan kepercayaan diri yaitu salah satunya dengan diskusi dan presentasi di kelas.

\section{SIMPULAN}

Berdasarkan hasil penelitian dan pembahasan maka dapat disimpulkan beberapa hal. Model pembelajaran kooperatif tipe STAD dalam penemuan terbimbing pada materi bangun ruang sisi datar efektif ditinjau dari prestasi belajar, kemampuan berpikir kritis, dan kepercayaan diri siswa SMP kelas VIII. Model pembelajaran kooperatif tipe TAI dalam penemuan terbimbing pada materi bangun ruang sisi datar efektif ditinjau dari prestasi belajar, kemampuan berpikir kritis, dan kepercayaan diri siswa SMP kelas VIII. Terdapat perbedaan keefektifan antara model pembelajaran kooperatif tipe STAD dalam penemuan terbimbing dengan model pembelajaran kooperatif tipe TAI dalam penemuan terbimbing pada materi bangun ruang sisi datar ditinjau dari prestasi belajar dan kemampuan berpikir kritis, namun tidak terdapat perbedaan ditinjau dari kepercayaan diri siswa SMP kelas VIII.

Sebagai tindak lanjut dari hasil penelitian ini dapat dikemukakan beberapa saran. Pendidik agar dalam menerapkan model pembelajaran kooperatif tipe STAD dan tipe TAl dalam penemuan terbimbing dapat mempersiapkan bahan ajar, LKS, alat dan bahan serta rencana pembelajaran yang memberi kesempatan lebih luas kepada siswa mengeksplorasi pengetahuannya secara mandiri. Pendidik untuk dapat menciptakan suasana belajar yang kondusif dan hendaknya lebih sering memotivasi siswa untuk saling bertanggung jawab terhadap pemahaman materi, yang memberi peluang terjadinya kolaborasi melalui interaksi antara guru dengan siswa, siswa dengan siswa lainnya dan siswa dengan materi ajarnya. Kolaborasi yang demikian akan memberi pengalaman belajar matematika yang berkesan dan menyenangkan sehingga membiasakan siswa bekerja sama, memiliki rasa tanggung jawab, berani mengemukakan pendapat, dan yakin akan kemampuan diri. Disarankan kepada para peneliti lain, apabila ingin melakukan penelitian yang sejenis sebaiknya tunjukkan kompetensi lain seperti aljabar. Kemudian untuk melihat perbedaan siswa pada ranah kognitifnya dapat dilihat kemampuan matematis lain seperti kemampuan berpikir berpikir kreatif, kemampuan komunikasi matematis dan kemampuan pemecahan masalah, sehingga memungkinkan generalisasi yang lebih luas.

\section{DAFTAR PUSTAKA}

Adesoji, A., \& Ibraheem. L. (2009). Effects of student teams-achievement divisions strategy and mathematics knowledge on learning outcomes in chemical kinetics. The Journal of International Social Research, 2(6), 1525. Retrieved from http://www.sosyalarastirmalar.com/cilt2/sayi6pdf/adesoji_ibraheem.pdf 
Amiluddin, R., \& Sugiman, S. (2016). Pengaruh problem posing dan PBL terhadap prestasi belajar, dan motivasi belajar mahasiswa pendidikan matematika. Jurnal Riset Pendidikan Matematika, 3(1), 100 -108. doi: http://dx.doi.org/10.21831/jrpm.v3i1.7303

Apino, E. (2016). Efektivitas guided discovery setting think pair share untuk meningkatkan prestasi dan toleransi. Prosiding Seminar Matematika dan Pendidikan Matematika, FKIP Universitas Sebelas Maret.

Arend, B. (2009). Encouraging critical thinking in online threaded discussions. The Journal Educator Online, 6(1), 123. doi: https://doi.org/10.9743/jeo.2009.1.1

Arends, R. I., \& Kilcher, A. (2010). Teaching for student learning becoming an accomplished teacher. New York, NY: Routledge.

Arthur, J., Grainger, T., \& Wray, D (2006). Learning to teach in the primary school. New York, NY: Routledge.

Bassham, G., Irwin, W., Nardone, H., \& Wallace, J.M., (2011). Critical thinking: A student's introduction (4th ed.) New York, NY: McGraw-Hill.

Borich, G. D. (2007). Effective teaching methods: Research-based practice (6thed.). Upper Saddle River, NJ: Pearson Education.

BSNP. (2012). Laporan hasil sekolah ujian nasional SMP/MTS tahun pelajaran 2011/2012.

BSNP. (2013). Laporan hasil sekolah ujian nasional SMP/MTS tahun pelajaran 2012/2013.

Cai, J., Kaiser, G., Perry, B., \& Wong, N.Y. (2009). Effective mathematics teaching from teacher perspectives. Rotterdam: Sense Publishers.

Castronova, J. (2002). Discovery learning for the 21st century: What is it and how does it compare to traditional learning ineffectiveness in the 21st century? Action Research Exchange, 1(1), 1-12. Retrieved from http://hdl.handle.net/10428/1257

Dahar, R. W. (2011). Teori-teori belajar dan pembelajaran. Jakarta: Erlangga.

Dean, J. (2000). Improving children's learning. London: Routledge.

Eggen, P., \& Kauchak, D. (2012). Strategi dan model pembelajaran (S. Wahono, Trans.). Jakarta: Indeks (Original work published 2012)

Ghufron, M. N., \& Risnawita, S. R. (2010). Teori-teori psikologi. Yogyakarta: Ar-Ruzz Media.

Hannula, M. S., Maijala, H., \& Pehkonen, E. (2004). Development of understanding and self confidence in mathematics; grades 5-8. Proceedings of the 28th Conference of the International Group for Psychology of Mathematics Education (Vol. 3, pp.17-24). Retrieved from https://files.eric.ed.gov/fulltext/ED489565.pdf

Herrmann, K. J. (2013). The impact of cooperative learning on student engagement: Results from an intervention. Active Learning in Higher Education, 14(3), 175-187. doi: https://doi.org/10.1177/1469787413498035

JIST Life. (2006). Young person's character education handbook. Indianapolis, IN: JIST Publishing.

Johnson, R. A., \& Wichern, W. D. (2007). Applied multivariate statistical analysis (7th ed.). Upper Saddle River, NJ: Pearson Prentice Hall.

Jurdak, M. (2009). Toward equity in quality in mathematics education. New York, NY: Springer.

Kemp, J. E., Morrison, G. R., \& Ross, S. M. (1994). Designing effective instruction. New York, NY: Merrill Publishing.

Kuebli, J. E., Harvey, R. D., \& Korn, J. H. (2008). Critical thinking in critical course: Principles and applications. In D. S. Dunn, J. S. Halonen, \& R. A. Smith (Eds.), Teaching critical thinking in psychology: A handbook of best practices (pp.137-148). Chichester, UK: John Willey \& Sons.

Kyriacou, C. (2009). Effective teaching in school: Theory and practice. Cheltenham, MD: Nelson Thornes. 
Lawrence, A. A. S, \& Vimala, A. (2012). School environment and academic achievement of standard IX students. Journal of Educational and Instructional Studies in the World, 2(3), 211-212. Retrieved from http://www.wjeis.org/FileUpload/ds217232/File/wjeis_2012.3.complete.pdf

Lefrancois, G. R. (1985). Phycology for teaching (5th ed.). Belmont, CA: Wadsworth.

Lie, A. (2004). Cooperative learning: Mempraktekkan cooperative learning di ruang-ruang kelas. Jakarta: PT Gramedia Widiasarana Indonesia.

Linn, R., Bond, L., Carr, P., Darling-Hammond, L., Harris, D., Hess, F., \& Shulman, L. (2009). Student learning, student achievement: How do teacher measure up. Arlington: National Board for Professional Teaching Standards (NBPTS).

Manning, G. \& Curtis, K. (2003). The art of leadership. New York. McGrawHill.

Martyanti, A. (2016). Keefektifan pendekatan problem solving dengan setting STAD dan TAI ditinjau dari prestasi dan selfconfidence. Jurnal Riset Pendidikan Matematika, 3(1), 1-15. doi: http://dx.doi.org/10.21831/jrpm.v3i1.9825

Mayer, R. E. (January 2004). Should there be a three-strikes rule against pure discovery learning; the case for guided method of instruction. American Psychologist, 59(1), 14-19. doi: https://doi.org/10.1037/0003-066X.59.1.14

Molla, E., \& Muche, M. (2018). Impact of cooperative learning approaches on students' academic achievement and laboratory proficiency in biology subject in selected rural schools, Ethiopia. Education Research International, 2018, 1-9. doi: https://doi.org/10.1155/2018/6202484

Munawaroh, M. (2006). Efektivitas Model Pembelajaran Kooperatif Tipe TAl Ditinjau dari Prestasi Belajar Matematika Siswa SMP N 3 Wonosari Kelas VIII (Skripsi tidak diterbitkan). FMIPA Universitas Negeri Yogyakarta, Yogyakarta.

Nneji, L. (2011). Impact of framing and team assisted individualized instructional strategies students' achievement in basic science in the north central zone of Nigeria. Journal of Knowledge Review, 23(4), 1-8.

Orlich, D. C., Harder, R. J., Callahan, R. C., Trevisan, M. S., \& Brown, A. H. (2010). Teaching strategies: A guide to effective instruction (9th ed.). Boston, MA: Wadsworth.

Renstein, A., \& Lander, G. H. (1990). Developing critical thinking in college programs. Research in Higher Education Journal, 1, 60-71. Retrieved from https://www.aabri.com/manuscripts/RHEJ-V1.pdf

Sari, D. P., Nurochmah, N., Haryadi, H., \& Syaiturjim, S. (2016). Meningkatkan kemampuan pemahaman matematis melalui pendekatan pembelajaran student teams achievement division. Jurnal Riset Pendidikan Matematika, 3(1), 16-22. doi: http://dx.doi.org/10.21831/jrpm.v3i1.7547

Shininger, K. A. (2006). The benefits of using STAD in a middle school mathematics classroom (Tesis magister tidak diterbitkan). Defiance College, Clinton St. Defiance, $\mathrm{OH}$.

Slavin, R. E. (1995). Cooperative learning: Theory, research, and practice (2nd ed.). Boston, MA: Allyn and Bacon.

Slavin, R. E. (2006). Educational psychology: Theory and practice. Boston,MA: Allyn and Bacon.

Srivastava, S. K. (2013). To study the effect of academic achievement on the level of self confident. Journal of Psychosocial Research, 8(1), 41- 51. Retrieved from https://www.questia.com/library/journal/1P33079013091/to-study-the-effect-of-academic-achievement-on-the

Stevens, J. (2009). Applied multivariate statistics for the social sciences (7th ed.). Mahwah, NJ: Lawrence Erlbaum Associates.

Suherman, E, (2003). Strategi pembelajaran matematika kontemporer. Bandung: UPI.

Susanti, V. D., Budiyono, B., \& Sujadi, I. (2013). Perbandingan prestasi belajar matematika siswa dengan pendekatan CTL antara model pembelajaran kooperatif tipe STAD dan NHT pada pokok bahasan sistem persamaan linier dua variabel ditinjau dari kepercayaan diri siswa kelas VIII SMP Negeri di Kabupaten 
PYTHAGORAS: Jurnal Pendidikan Matematika, 14 (2), 2019 - 162 Endah Octaningrum Wahani Sejati, Djamilah Bondan Widjajanti

Madiun. Jurnal Pembelajaran Matematika, 1(3), 297-305. Retrieved from https://jurnal.fkip.uns.ac.id/index.php/s2math/article/view/3504/2439\#

Trianto, T. (2009). Mendesain model pembelajaran inovatif-progresif: Konsep, landasan, dan implementasinya pada Kurikulum Tingkat Satuan Pendidikan (KTSP). Jakarta: Prenada Media Group.

Warsita, B. (2008). Teknologi pembelajaran: Landasan dan teorinya. Jakarta: PT Rineka Cipta.

Wartiningsih, K. (2011). Pengaruh model kooperatif pada pembelajaran trigonometri terhadap prestasi akademik, tolerasnsi, dan kepercayaan diri siswa SMAN di Klaten (Tesis magister tidak diterbitkan). Universitas Negeri Yogyakarta, Yogyakarta.

Westwood, P. (2008). What teachers need to know about teaching methods. Camberwell, VIC: ACER Press.

Widoyoko, E. P. (2009). Evaluasi program pembelajaran. Yogyakarta: Pustaka Pelajar.

Yasna, L. T. (2016). Pembelajaran matematika dengan pendekatan cooperative learning ditinjau dari prestasi belajar, motivasi, dan akhlak mulia siswa. Pythagoras: Jurnal Pendidikan Matematika, 11(1), 45-58. doi: http://dx.doi.org/10.21831/pg.v11i1.9676

Zakaria, E., Chin, L. C., \& Daud, M. Y. (2010). The effects of cooperative learning on students' mathematics achievement and attitude towards mathematics. Creative Education, 4(2), 98- 100 . doi: https://doi.org/10.4236/ce.2013.42014 